\title{
REVIEW
}

\section{Earlier diagnosis and earlier treatment of COPD in primary care}

\author{
*David Pricea , Daryl Freemana, Jen Cleland ${ }^{\mathrm{a}}$, Alan Kaplan', Frank Cerasolic \\ ${ }^{a}$ Centre of Academic Primary Care, University of Aberdeen, Aberdeen, UK \\ ${ }^{\mathrm{b}}$ Chairperson, Family Physician Airways Group of Canada, Richmond Hill, Ontario, Canada \\ Pfizer Inc, New York, NY, USA
}

Originally submitted 31st March 2010; resubmitted 2nd June 2010; revised version received 23rd July 2010; accepted 29th July 2010; online 24th September 2010

\begin{abstract}
Chronic obstructive pulmonary disease (COPD) is a progressive disease that begins many years before a diagnosis is usually made. The need for an early and confirmed diagnosis of COPD is increasingly appreciated by primary care physicians in whose hands the ability to make improvements in early diagnosis largely rests. Case-finding of patients with symptoms of lifestyle limitation is probably the most practical way to achieve early diagnosis. Evidence suggests a burden of early COPD on afflicted people and their families. Early encouragement of smoking cessation, in conjunction with management of symptoms and treating activity limitation and exacerbations by appropriate non-pharmacologic and pharmacologic management at the earliest possible stage, could positively affect the impact and progression of the disease.

(C) 2011 Primary Care Respiratory Society UK. All rights reserved.

D Price et al. Prim Care Respir J 2011; 20(1): 15-22

doi:10.4104/pcrj.2010.00060
\end{abstract}

Keywords COPD, early diagnosis, early treatment, primary care

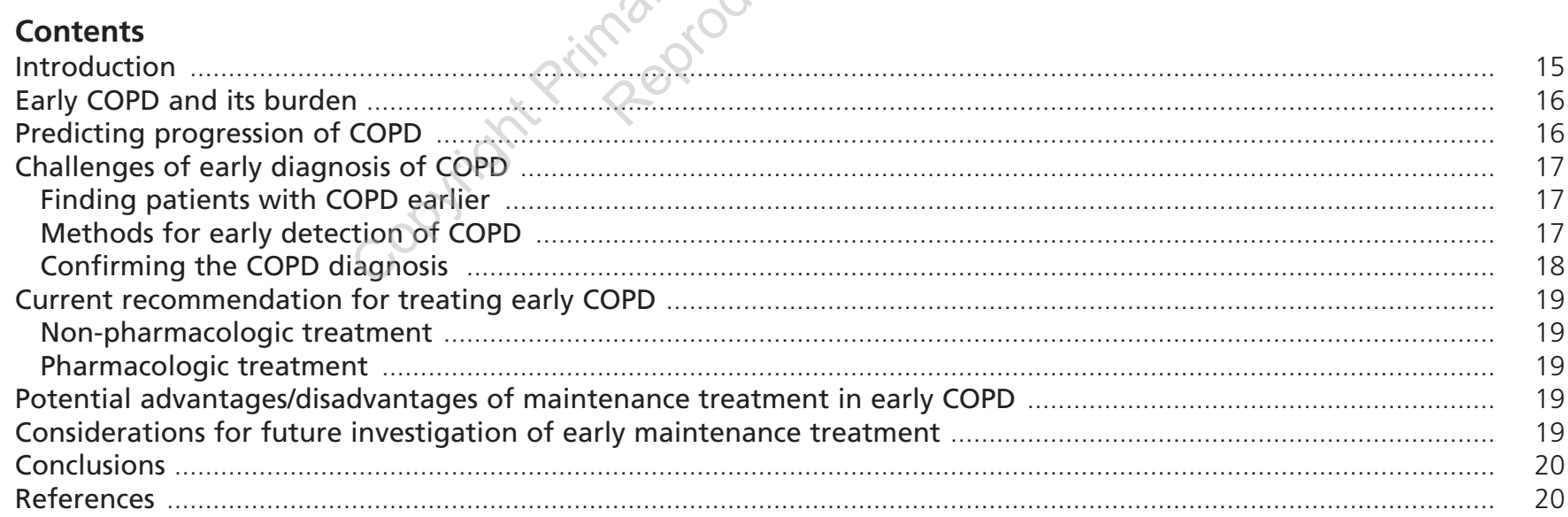

\section{See linked editorial by Enright and White on page 6}

\section{Introduction}

Chronic obstructive pulmonary disease (COPD) progressively debilitates patients, resulting in increasing disability and worsening impact of exacerbations. ${ }^{1}$ Many patients with COPD remain undiagnosed and potentially unknown to healthcare providers until the more advanced stages of the disease.' Delayed diagnosis results in patients suffering symptoms and limitations that could otherwise be alleviated by treatment. Moreover, potential opportunities to disrupt the progressive nature of COPD may be forfeited.

\footnotetext{
* Corresponding author: Professor David Price, Centre of Academic Primary Care, University of Aberdeen, Foresterhill Health Centre, Westburn Road, Aberdeen, Scotland, AB25 2AY, UK. Tel: +44 (0)1224 554588 Fax: +44 (0)1224 840683 E-mail: david@respiratoryresearch.org
} 
Recent evidence from Spain suggests that a large majority of COPD patients remain undiagnosed; when these undiagnosed patients were identified, nearly $95 \%$ of the patients had early COPD of mild and moderate severity $(56.4 \%$ and $38.3 \%$ for Global initiative for chronic Obstructive Lung Disease [GOLD] Stage I and II, respectively). ${ }^{2}$ In the UK, a study of adults aged over 35 years suggests that more than $80 \%$ of those meeting GOLD spirometric criteria for COPD reported having no respiratory diagnosis. ${ }^{3}$ Even among those with severe or very severe airflow obstruction, less than half were diagnosed. ${ }^{3}$

Despite being distinct conditions, COPD is often misdiagnosed as asthma due to the overlap of symptoms. ${ }^{4,5}$ In the UK- and US-based study by Tinkelman and colleagues, ${ }^{4} 1$ in 4 patients previously diagnosed with asthma were diagnosed during the study as having COPD.

Many countries are developing methods to assist with identifying and confirming early COPD. ${ }^{6}$ Campaigns are in place to increase public awareness of the disease and promote the presentation of COPD symptoms by patients to their doctors. These efforts may be having an impact given recent evidence that the percentage of patients diagnosed with GOLD Stage I may be increasing. ${ }^{7}$ This article discusses the issues of early stage COPD, including its burden, the challenges of diagnosis, the need to identify COPD patients earlier in the course of their disease, and highlights how patients with early COPD could benefit from non-pharmacologic and maintenance pharmacologic treatment.

\section{Early COPD and its burden}

Early COPD, with symptoms that may or may not be recognised, may express itself in many ways. Regardless of the expression, it can be characterised by variable damage to lung tissue and/or airway inflammation, ${ }^{8}$ all or one of which can lead to spirometry changes. . $^{-11}$ )

The GOLD guidelines define the severity of COPD primarily in terms of airflow obstruction, such as forced expiratory volume in one second $\left(\mathrm{FEV}_{1}\right)$ and other spirometry parameters.' While these are undoubtedly useful for staging the disease, a degree of airway obstruction is not the beginning of COPD. In this article, 'early COPD' refers to the initial, insidious stages of the disease through to moderate airflow limitation (GOLD Stage II) - i.e., the earliest stage at which many patients typically first seek medical attention. Furthermore, 'earlier diagnosis' refers to identifying and diagnosing COPD before airflow limitation is so great that patients seek medical attention for that reason.

COPD at an early stage may be expressed in different ways. Some patients may appear to be asymptomatic; however, probably more accurately, asymptomatic individuals are affected in ways that are difficult to perceive or measure, and which can easily be dismissed as being attributed to ageing. Undiagnosed GOLD stage I COPD may already show signs of impaired daily activities and health-related quality of life (HRQoL). ${ }^{2}$ Undetected activity limitation leads to changes in lifestyle, deconditioning and an increased risk of social isolation and depression. 12,13 Conversely, patients with pathological processes that may lead to COPD may be overtly symptomatic, yet show no outward signs of airway obstruction. Their symptoms may include a persistent cough (associated with an increased risk of COPD development), ${ }^{14}$ excessive sputum production or recurring chest infections, none of which are specific for COPD, thereby adding to the challenge of correct diagnosis, especially if spirometry is not used. 15,16

COPD exacerbations occur regularly in patients with more severe disease; however, they occur in patients with milder COPD as well. ${ }^{17}$ Patients experiencing frequent exacerbations have an accelerated loss of lung function, more rapid disease progression and decreased quality of life, compared with infrequent exacerbators. ${ }^{18,19}$ Exacerbations may be especially surprising and debilitating among patients with mild COPD, and substantially impact on work productivity and health resource use. Thus, the clinical, social and economic importance of COPD exacerbations cannot be underestimated and focus should be given to their prevention..$^{20,21}$ Furthermore, the incidence of exacerbations in the early stages of COPD may be much higher than expected, since many exacerbations in milder COPD patients are likely to be unreported. ${ }^{17,22}$

\section{Predicting progression of COPD}

The pioneering work of Fletcher and Peto demonstrated that the progressive and rapid decline in $\mathrm{FEV}_{1}$ is the hallmark of COPD progression. ${ }^{23}$ In this landmark study of working men in England, mean rates of decline in $\mathrm{FEV}_{1}$ within the population were dependent on whether patients continued to smoke. More recent studies confirmed and extended these findings; for example, the Lung Health Study and others showed the average linear rate of $\mathrm{FEV}_{1}$ decline in COPD is approximately $60 \mathrm{~mL} / \mathrm{year},{ }^{24-27}$ which is double the rate of decline in nonCOPD subjects. ${ }^{24}$

While the Fletcher and Peto study suggested that the rate of $\mathrm{FEV}_{1}$ decline becomes more rapid as COPD patients age, ${ }^{23}$ recent evidence suggests that the rate of $\mathrm{FEV}_{1}$ decline is greater in patients with less severe disease than those with more severe disease. Data in the appendices from the Understanding Potential Long-term Impacts on Function with Tiotropium $\left(\mathrm{UPLIFT}^{\oplus}\right)$ trial ${ }^{28}$ suggest a more rapid rate of decline in postbronchodilator $\mathrm{FEV}_{1}$ in patients with GOLD Stage II versus GOLD Stages III and IV. ${ }^{29}$ A similar pattern was shown in a secondary analysis from the TOwards a Revolution in COPD Health (TORCH) study of patients sub-grouped by baseline FEV $1 .{ }^{30,31}$ 
Linking the rate of $\mathrm{FEV}_{1}$ decline and progression of COPD to symptom severity is a rational and attractive construct for practitioners. Supporting evidence comes from recent studies demonstrating that symptomatic GOLD Stage I COPD patients exhibit a faster rate of $F E V_{1}$ decline than asymptomatic GOLD Stage I patients in whom the decline in $\mathrm{FEV}_{1}$ is no greater than a 'normal' reference group. ${ }^{32}$ Caution must be used because often the rate of $F E V_{1}$ decline or the severity of $F E V_{1}$ limitations is an imperfect predictor of symptoms. ${ }^{24,33}$ The converse is also true; hence, progression of COPD in terms of symptoms may be more complex than decline in $\mathrm{FEV}_{1}$ alone. For example, exercise tolerance ${ }^{34}$ and $\mathrm{HRQOL}^{35}$ are known to decline with only a weak association to $\mathrm{FEV}_{1}$ over time.

\section{Challenges of early diagnosis of COPD}

As identified above, several key challenges hinder the early diagnosis of COPD. A first challenge is to encourage patients to recognise and present their symptoms (such as coughing, decreasing physical activity/exertion, mild breathlessness) rather than dismiss them as the result of normal physiological changes (e.g., ageing or gaining weight). Another challenge is for the physician to be attuned to the propensity to dismiss early COPD symptoms and focus solely on the acutely vexing symptoms with which patients present. A third challenge is to discern early COPD from asthma or other conditions with similar symptoms.

\section{Finding patients with COPD earlier}

Many patients are diagnosed after considerable damage has occurred to the lungs. This damage occurs slowly and the associated symptoms are typically only recognised at more severe stages (GOLD Stages III to IV). Even at this stage, COPD diagnosis may not be a first or second consideration. This has been recognised by COPD awareness initiatives such as GOLD and the US COPD Coalition, ${ }^{1,6}$ which attempt to raise awareness of COPD among the general public as well as medical professionals. Additionally, strategies within primary care such as active casefinding (e.g., targeting of smokers over 40 years of age with case-finding questionnaires) may have an important impact. ${ }^{36-38}$

Worldwide efforts to identify patients with COPD are providing encouraging results. The Detection, Interaction and Monitoring of COPD and Asthma project (DIMCA), being conducted in The Netherlands, screens the general adult population for COPD' ${ }^{39}$ as well as asthma, whilst the 'Know the Age of Your Lung' project in Poland is more targeted to at-risk populations and screens current and former smokers aged above 40 years. ${ }^{40} \mathrm{Awareness}$ programmes may be limited by cost; for example, the estimated cost per detected case in 'Know the Age of Your Lung' is between $\$ 500$ and $\$ 1000$, depending on the screening method. ${ }^{41}$ However, no indications of increased costs, above those of average care plus screening, are observed in the DIMCA project. ${ }^{41}$ Moreover, in the UK, opportunistic case finding in primary care, using spirometry linked to smoking cessation, is shown to be cost effective. ${ }^{42}$

\section{Methods for early detection of COPD}

Spirometry is the most reliable detection method for COPD. Case identification spirometry may improve early detection and management (including aggressive smoking cessation) by excluding patients with normal lung function and identifying patients who may require further evaluation using diagnostic spirometry. ${ }^{36-38}$ The International Primary Care Respiratory Group (IPCRG) currently recommends case identification spirometry in all patients over 35 years who present with respiratory symptoms and risk factors, such as prior or current smoking history. ${ }^{38}$

Diagnostic spirometry using more stringent criteria (postbronchodilator $\mathrm{FEV}_{1} /$ forced vital capacity (FVC) ratio of $<0.7^{1}$ versus $F E V_{1} / F V C \leq 0.8$ for case-finding spirometry ${ }^{38}$ ) should be offered to patients in whom the possibility of COPD cannot be excluded.

Despite its importance in identifying patients with COPD, ${ }^{39,43}$ many primary care physicians decide not to incur

\section{Table 1. COPD questionnaire, to be used in patients presenting with a history suggestive of COPD and who are not suspected of having asthma. ${ }^{52}$}

\begin{tabular}{|c|c|c|}
\hline What is your age? & $\begin{array}{l}40-49 \text { years } \\
50-59 \text { years } \\
60-69 \text { years } \\
70 \text { years or older }\end{array}$ & $\begin{array}{c}0 \\
4 \\
8 \\
10\end{array}$ \\
\hline $\begin{array}{l}\text { What is your height in metres? } \\
\text { What is your weight in kilograms? }\end{array}$ & $\begin{array}{l}\text { Calculated BMI }<25.4 \\
\text { Calculated BMI 25.4-29.7 } \\
\text { Calculated BMI }>29.7\end{array}$ & $\begin{array}{l}5 \\
1 \\
0\end{array}$ \\
\hline $\begin{array}{l}\text { How many pack-years of cigarettes } \\
\text { have you smoked? }\end{array}$ & $\begin{array}{l}0-14 \text { pack years } \\
15-24 \text { pack years } \\
25-49 \text { pack years } \\
50+\text { pack years }\end{array}$ & $\begin{array}{l}0 \\
2 \\
3 \\
7\end{array}$ \\
\hline Does the weather affect your cough? & $\begin{array}{l}\text { Yes } \\
\text { No }\end{array}$ & $\begin{array}{l}3 \\
0\end{array}$ \\
\hline $\begin{array}{l}\text { Do you ever cough up phlegm } \\
\text { (sputum) from your chest when you } \\
\text { don't have a cold? }\end{array}$ & $\begin{array}{l}\text { Yes } \\
\text { No }\end{array}$ & $\begin{array}{l}3 \\
0\end{array}$ \\
\hline $\begin{array}{l}\text { Do you usually cough up phlegm } \\
\text { (sputum) from your chest first thing } \\
\text { in the morning? }\end{array}$ & $\begin{array}{l}\text { Yes } \\
\text { No }\end{array}$ & $\begin{array}{l}0 \\
3\end{array}$ \\
\hline How frequently do you wheeze? & $\begin{array}{l}\text { Never } \\
\text { Occasionally or } \\
\quad \text { more often }\end{array}$ & 0 \\
\hline $\begin{array}{l}\text { Do you have or have you had } \\
\text { any allergies? }\end{array}$ & $\begin{array}{l}\text { Yes } \\
\text { No }\end{array}$ & $\begin{array}{l}0 \\
3\end{array}$ \\
\hline \multicolumn{3}{|c|}{$\begin{array}{l}\text { Scoring system: } \\
\text { Add up the total number of points based on the patient's response. } \\
\text { - } 16 \text { or fewer points suggests a diagnosis other than COPD, } \\
\text { probably asthma } \\
\text { - } 17 \text { or more points suggests a diagnosis of COPD }\end{array}$} \\
\hline
\end{tabular}


Table 2. Differential diagnosis of COPD.*

\begin{tabular}{|c|c|}
\hline Diagnosis & Suggestive features \\
\hline COPD & $\begin{array}{l}\text { - Onset in mid-life } \\
\text { - Symptoms slowly progressing } \\
\text { - Dyspnoea during exercise } \\
\text { - Largely irreversible airflow limitation }\end{array}$ \\
\hline Asthma & $\begin{array}{l}\text { - Onset early in life (often childhood) } \\
\text { - Symptoms vary from day to day } \\
\text { - Symptoms at night/early morning } \\
\text { - Allergy, rhinitis and/or eczema also present } \\
\text { - Family history of asthma } \\
\text { - Largely irreversible airflow limitation }\end{array}$ \\
\hline $\begin{array}{l}\text { Congestive heart } \\
\text { failure }\end{array}$ & $\begin{array}{l}\text { - Fine basilar crackles on auscultation } \\
\text { - Chest X-ray shows dilated heart, } \\
\text { pulmonary oedema } \\
\text { - Pulmonary function tests indicate } \\
\text { volume restriction, not airflow limitation }\end{array}$ \\
\hline Bronchiectasis & $\begin{array}{l}\text { - Large volumes of purulent sputum } \\
\text { - Commonly associated with bacterial infection } \\
\text { - Coarse crackles/clubbing on auscultation } \\
\text { - Chest X-ray/CT shows bronchial dilation, } \\
\text { bronchial wall thickening }\end{array}$ \\
\hline Tuberculosis & $\begin{array}{l}\text { - Onset all ages } \\
\text { - Chest X-ray shows lung infiltrate } \\
\text { - Microbiological confirmation } \\
\text { - High local prevalence of tuberculosis }\end{array}$ \\
\hline $\begin{array}{l}\text { Obliterative } \\
\text { bronchiolitis }\end{array}$ & $\begin{array}{l}\text { - Onset in younger age, non-smokers } \\
\text { - May have history of rheumatoid arthritis } \\
\text { - } \text { or fume exposure } \\
\text { - CT on expiration shows hypodense areas }\end{array}$ \\
\hline $\begin{array}{l}\text { Diffuse } \\
\text { pan-bronchiolitis }\end{array}$ & $\begin{array}{l}\text { - Most patients are male and non-smokers } \\
\text { - Almost all have chronic sinusitis } \\
\text { - Chest X-ray and HRCT show diffuse small } \\
\text { centrilobular nodular opacities } \\
\text { and hyperinflation }\end{array}$ \\
\hline
\end{tabular}

* These features tend to be characteristic of the respective diseases but do not occur in every case. For example, a person who has never smoked may develop COPD (especially in the developing world where other risk factors may be more important than cigarette smoking); asthma may develop in adult and even elderly patients.

$\mathrm{CT}=$ Computerised tomography; $\mathrm{HRCT}=$ High resolution computed tomography.

the cost of spirometry equipment; others may be intimidated by the complexity of the technology, the meaning of the results and interpretation to the patients, or may lack time and motivation. ${ }^{2,44,45}$ Patient questionnaires are an effective alternative, or add-on, case-finding tool for discriminating between persons with and without COPD. ${ }^{36,38,46-49}$ Questions include items on age, body mass index (BMI), smoking intensity, cough, phlegm, dyspnoea on exertion and wheeze, as well as prior diagnosis consistent with asthma or COPD. ${ }^{50,51}$ Questions on all these factors, other than dyspnoea, are included in the COPD questionnaire recommended in the IPCRG guidelines ${ }^{38}$ for diagnosis of respiratory diseases in primary care (Table 1). ${ }^{52}$ Individuals considered at risk of having early stage COPD, by either method, should be
Table 3. Differential diagnosis questionnaire to determine between COPD and asthma. ${ }^{38,56}$

\begin{tabular}{|c|c|c|}
\hline & Response choices & Points \\
\hline What is your age? & $\begin{array}{l}40-49 \text { years } \\
50-59 \text { years } \\
60-69 \text { years }\end{array}$ & $\begin{array}{l}0 \\
5 \\
9\end{array}$ \\
\hline $\begin{array}{l}\text { How many pack years of } \\
\text { cigarettes have you smoked? }\end{array}$ & $\begin{array}{l}0-14 \text { pack years } \\
15-24 \text { pack years } \\
25-49 \text { pack years } \\
50+\text { pack years }\end{array}$ & $\begin{array}{l}0 \\
3 \\
7 \\
9\end{array}$ \\
\hline $\begin{array}{l}\text { Have you coughed more in the last } \\
\text { few years? }\end{array}$ & $\begin{array}{l}\text { Yes } \\
\text { No }\end{array}$ & $\begin{array}{l}0 \\
1\end{array}$ \\
\hline $\begin{array}{l}\text { During the past } 3 \text { years, have you } \\
\text { had any breathing problems that } \\
\text { have kept you off work, indoors, } \\
\text { at home or in bed? }\end{array}$ & $\begin{array}{l}\text { Yes } \\
\text { No }\end{array}$ & $\begin{array}{l}0 \\
3\end{array}$ \\
\hline $\begin{array}{l}\text { Have you ever been admitted to } \\
\text { hospital with breathing problems? }\end{array}$ & $\begin{array}{l}\text { Yes } \\
\text { No }\end{array}$ & $\begin{array}{l}6 \\
0\end{array}$ \\
\hline $\begin{array}{l}\text { Have you been short of breath more } \\
\text { often in the past few years? }\end{array}$ & $\begin{array}{l}\text { Yes } \\
\text { No }\end{array}$ & $\begin{array}{l}1 \\
0\end{array}$ \\
\hline $\begin{array}{l}\text { On average, how much phlegm } \\
\text { (sputum) do you cough up most } \\
\text { days? }\end{array}$ & $\begin{array}{l}\text { None or less than } \\
1 \text { tablespoon ( } 15 \mathrm{~mL} \\
\text { or } 1 / 2 \text { oz) per day } \\
1 \text { tablespoon ( } 15 \mathrm{~mL} \\
\text { or } 1 / 2 \mathrm{oz} \text { ) or more } \\
\text { per day }\end{array}$ & L \\
\hline $\begin{array}{l}\text { If you get a cold, does it usually } \\
\text { go to your chest? }\end{array}$ & $\begin{array}{l}\text { Yes } \\
\text { No }\end{array}$ & $\begin{array}{l}4 \\
0\end{array}$ \\
\hline $\begin{array}{l}\text { Are you taking any treatment to } \\
\text { help your breathing? }\end{array}$ & $\begin{array}{l}\text { Yes } \\
\text { No }\end{array}$ & $\begin{array}{l}5 \\
0\end{array}$ \\
\hline \multicolumn{3}{|c|}{$\begin{array}{l}\text { Scoring system: } \\
\text { Add up the total number of points based on the patient's response. } \\
\text { - } 18 \text { or fewer points suggests a diagnosis of asthma } \\
\text { - } 19 \text { or more points suggests a diagnosis of COPD }\end{array}$} \\
\hline
\end{tabular}

referred for diagnostic assessment, which may require referral to specialist spirometry services.

\section{Confirming the COPD diagnosis}

The differential diagnosis for COPD can be complex. Several disorders may present with similar symptoms, signs and spirometry results (Table 2), including asthma, bronchiectasis and carcinoma of the bronchus. ${ }^{142}$ Furthermore, many of these conditions can co-exist with COPD, particularly those associated with cigarette smoking. A chest $x$-ray is recommended by most guidelines to assist in excluding some of these differential diagnoses (see Table 2). ${ }^{1,42,53,54}$

Asthma remains the most common differential diagnosis and is difficult to distinguish from the early stages of COPD. Differentiation of asthma from COPD is confirmed through an $\mathrm{FEV}_{1} / \mathrm{FVC}$ ratio after inhalation of a bronchodilator. ${ }^{1,42}$ As described above, a post-bronchodilator $\mathrm{FEV}_{1} / \mathrm{FVC}$ ratio of less than 0.70 is indicative of COPD.' Bronchodilation with a shortacting $\beta_{2}$-agonist is important since the prevalence of COPD 
may be over-estimated by $27 \%$ if spirometry is used without bronchodilation. ${ }^{55}$ Features from the history and examination should be used to assist in distinguishing COPD from asthma wherever possible, such as with the questionnaire for differential diagnosis of obstructive lung disease recommended in the IPCRG guidelines (Table 3)..$^{38,56}$

\section{Current recommendation for treating early COPD}

Evidence-based guidelines recommend a step-wise approach to the treatment of COPD, involving the use of both nonpharmacologic and pharmacologic therapies. ${ }^{1,22,53,54}$

\section{Non-pharmacologic treatment}

Non-pharmacologic therapies that are paramount to initial treatment success include the education of patients and the avoidance of risk factors; however, this is inconsistently provided to patients with early disease. ${ }^{57}$ Vaccination against pneumococcal and influenza viruses is recommended for all patients. ${ }^{1,42,53,54}$

Chief among non-pharmacological interventions is smoking cessation, which is essential in reducing lung function decline and has been shown to be beneficial even among the heaviest of smokers. ${ }^{24,33}$ The benefits of smoking cessation, notably on survival and disease progression, may be less evident in patients with more established disease, and may instead be restricted to milder, asymptomatic patients with measurable lung function impairment. ${ }^{58}$ This was demonstrated in the 30-year follow-up data from a population cohort from the Seven Countries study, ${ }^{59}$ in which significant reductions in mortality were observed in men aged 40-59 with impaired lung function who gave up smoking. The study demonstrated the likely changes that patients may experience following smoking cessation; however, it is possible that these benefits may not extend to all patients and some may not experience any change, regardless of their COPD stage.

All guidelines recommend that patients increase their physical activity levels. ${ }^{1,22,53,54}$ Structured exercise programmes improve exercise potential in more severe patients ${ }^{60}$ through reduced hyperinflation and muscle conditioning; when initiated in early stage disease, exercise is likely to improve future disability. ${ }^{61}$ Nevertheless, the value of physical activity may be poorly communicated and/or underappreciated by prescribing physicians, or be forgotten by some patients, since only a minority of patients report receiving this advice. ${ }^{57}$ Interventions in early COPD need to assist in changing a patient's attitudes to smoking and exercise. Performance enhancement through exercise may improve a patient's sense of health and initiate a positive cycle of activity and well-being that would otherwise be a cycle of decline.

\section{Pharmacologic treatment}

Pharmacologic therapy is crucial to the success of COPD management. Short-acting bronchodilators, as required, are recommended for breathlessness or reduced exercise capacity, regardless of airway obstruction. ${ }^{1,42,53,54}$ Maintenance therapy with long-acting bronchodilators (defined as medication taken regularly when symptoms are more than just intermittent) is recommended to manage chronic airflow limitation and symptoms. ${ }^{1,22,53,54}$ Exacerbations, if they occur during the course of maintenance therapy with one or more long-acting bronchodilators, may be additionally prevented by regular administration of inhaled corticosteroids. ${ }^{1,22,53,54}$

\section{Potential advantages/disadvantages of maintenance treatment in early COPD}

Much of the data supporting guidelines on pharmacologic interventions are derived from studies at least three years old and most often comprised of patients with severe COPD. However, recent investigations suggest greater benefits of identifying and treating COPD earlier rather than later. ${ }^{29,31,62}$

Multiple reports demonstrating improvements in lung function, dyspnoea and quality of life, reduced risk of exacerbations, and possibly decreased rate of lung function decline through earlier pharmacologic intervention, make it difficult to uphold the traditional pessimistic view that COPD is a disease that responds poorly to treatment. ${ }^{63}$ This seems particularly true in patients with early COPD. Maintenance bronchodilator treatment in patients with $\mathrm{FEV}_{1} \geq 50 \%$ predicted (GOLD Stage II) clearly improves lung function ( $\mathrm{FEV}_{1}$ ) to an extent greater than placebo, ${ }^{62,64}$ which also extends to patients with an FEV 1 of $\geq 60 \%$ predicted. ${ }^{65} \mathrm{~A}$ reduction in the frequency of exacerbations in patients with milder COPD is also suggested. $62,64,66$

Subanalyses from the UPLIFT ${ }^{\circledR}$ study demonstrate similar findings. For example, $\mathrm{FEV}_{1}$ improvements were greater in patients with GOLD Stage \| COPD $^{29}$ than the overall study population. ${ }^{28}$ These results were similar to those observed in the TORCH study in which greater improvements in $\mathrm{FEV}_{1}$ in response to chronic maintenance therapy were observed in GOLD Stage II patients compared with GOLD Stage III or IV. ${ }^{31}$ Improvements in lung function yielded greater improvements in the risk of exacerbations, ${ }^{29}$ the number of exacerbations per year, ${ }^{29,31}$ and hospitalisations resulting from exacerbations ${ }^{29}$ than similarly treated patients with either GOLD Stage III or IV. Maintenance pharmacologic therapies, given in the early stages of COPD may also improve the rate of $\mathrm{FEV}_{1}$ decline. ${ }^{28-31}$ Other secondary analyses of UPLIFT ${ }^{\circledR}$ suggest greater improvements in $\mathrm{FEV}_{1}$, rate of decline in post-bronchodilator $\mathrm{FEV}_{1}$, and symptoms, in COPD patients less than 50 years old, ${ }^{67}$ as well as those in which tiotropium was administered as first-line maintenance treatment of COPD. ${ }^{68}$

\section{Considerations for future investigation of early maintenance treatment}

Although interest in maintenance treatment in earlier COPD is 
increasing, much work is required before evidence-based guidelines are able to assess its potential adequately. Future trials could rigorously investigate the combined effects of maintenance pharmacotherapy, education and exercise management programmes in patients who have mild COPD. Furthermore, there is a requirement for additional studies in symptomatic GOLD Stage I patients with respect to quality of life, activity limitation, and response to management. Investigations in patients 'at risk' of COPD could follow patients longitudinally over a number of years so that progression of COPD can be reassessed in the context of recent longitudinal investigations designed with different purposes.

COPD is frequently associated with several co-morbidities, including vascular disease, osteoporosis, metabolic imbalances and depression. ${ }^{69}$ While the causal relationship between COPD and co-morbidities is not entirely clear, inactivity and systemic inflammation have been suggested as part of the mechanism for the co-morbidities associated with COPD and may relate to the natural course of the disease. ${ }^{14,69-73}$ For example, the incidence of early vascular disease is increased in people with COPD compared with smokers without COPD or non-smokers. ${ }^{74}$ Investigations that focus on the link between early COPD and the development of co-morbid conditions may be of considerable clinical value. Finally, another important question for study may be to determine the impact of the use of maintenance treatment on patient behaviours such as exercise and smoking.

\section{Conclusions}

Mounting evidence suggests that early detection, diagnosis, and maintenance treatment of COPD, alongside smoking cessation and exercise, may help provide the best symptom control, disease progression (whether spirometric or symptomatic) and outcomes in COPD. Specific, rigorous, clinical investigations testing this hypothesis should now be conducted to solidify the existing evidence. Early diagnosis of COPD should be viewed as an essential component of COPD care; primary care is the most pragmatic clinical setting in which this can be achieved. Case identification of patients with COPD risk factors and symptoms may be the most practical way to achieve early diagnosis. This requires changing attitudes of both physicians and patients, and raising awareness of COPD. Recognition of COPD symptoms, including mild limitations of physical activity, as well as others which are overlooked in early disease, needs to be at the forefront of physicians' minds when examining patients at risk of COPD, who often present for other ailments.

\section{Acknowlegements}

The authors would like to acknowledge Dr Bartolome Celli for his valuable input and contribution of ideas during the concept stage of this manuscript.

Writing and editorial assistance was provided by David Macari, PhD and Claire Scarborough, PhD of PAREXEL, which was contracted by Boehringer Ingelheim for these services. The authors meet criteria for authorship as recommended by the
International Committee of Medical Journal Editors (ICMJE) and were fully responsible for all content and editorial decisions, and were involved at all stages of the manuscript's development. The authors received no compensation related to the development of the manuscript.

\section{Conflict of interest declarations}

David Price has consultant arrangements with Aerocrine, Boehringer Ingelheim, Dey Pharmaceuticals, GlaxoSmithKline, Merck, Sharpe and Dohme, Novartis, ScheringPlough and Teva. He has received grants and research support for research in respiratory disease from UK National Health Service, Aerocrine, AstraZeneca, Boehringer Ingelheim, GlaxoSmithKline, Merck, Sharpe and Dohme, Novartis, Pfizer, Schering Plough and Teva. He has spoken for Boehringer Ingelheim, Chiesi, GlaxoSmithKline, Merck, Sharpe and Dohme, Pfizer and Teva. Daryl Freeman has no shares in pharmaceutical companies. She has received speaker's honoraria for speaking at sponsored meetings from the following companies marketing respiratory products: AstraZeneca, Boehringer Ingelheim, GlaxoSmithKline. She has received honoraria for advisory panels with AstraZeneca, and help with research projects from AstraZeneca, Boehringer Ingelheim and GlaxoSmithKline. Daryl receives funding for a clinical post from AstraZeneca \& Boehringer Ingelheim, and has recently been funded to attend an international conference by Nycomed \& Boehringer Ingelheim. Jennifer Cleland has received unconditional educational research grants from Pfizer, GlaxoSmithKline and Boehringer Ingelheim. Alan Kaplan has worked or consulted for the following companies: AstraZeneca, Bayer, Boehringer Ingeleheim, GlaxoSmithKline, Merck Frost, Novartis, Nycomed, Pfizer, Purdue, and Talecris. Frank Cerasoli is an employee of Pfizer Inc.

\section{References}

1. Global Initiative for Chronic Obstructive Lung Disease. Global strategy for the diagnosis, management, and prevention of chronic obstructive pulmonary disease. 2009 update. www.goldcopd.com. Last accessed 1-12-2009.

2. Miravitlles M, Soriano JB, Garcia-Rio F, et al. Prevalence of COPD in Spain: impact of undiagnosed COPD on quality of life and daily life activities. Thorax 2009;64:863-8.

3. Shahab L, Jarvis MJ, Britton J, West R. Prevalence, diagnosis and relation to tobacco dependence of chronic obstructive pulmonary disease in a nationally representative population sample. Thorax 2006;61:1043-7. http://dx.doi.org/ 10.1136/thx.2006.064410

4. Tinkelman DG, Price DB, Nordyke RJ, Halbert RJ. Misdiagnosis of COPD and asthma in primary care patients 40 years of age and over. J Asthma 2006; 43:75-80. http://dx.doi.org/10.1080/02770900500448738

5. Chang J, Mosenifar Z. Differentiating COPD from asthma in clinical practice. J Intensive Care Med 2007; 22:300-09. http://dx.doi.org/10.1177/ 0885066607304445

6. Zielinski J, Bednarek M, Gorecka D, et al. Increasing COPD awareness. Eur Respir J 2006;27:833-52. http://dx.doi.org/10.1183/09031936.06.00025905

7. Soriano JB, Ancochea J, Miravitlles M, et al. Recent trends in COPD prevalence in Spain: a repeated cross-sectional survey 1997-2007. Eur Respir J 2009 [Epub ahead of print].

8. Hogg JC, Chu F, Utokaparch S, et al. The nature of small-airway obstruction in chronic obstructive pulmonary disease. N Engl J Med 2004;350:2645-53. http://dx.doi.org/10.1056/NEJMoa032158

9. Pratt PC, Kilburn $\mathrm{KH}$. A modern concept of the emphysemas based on correlations of structure and function. Hum Pathol 1970;1:443-63.

10. Holme J, Stockley RA. Radiologic and clinical features of COPD patients with discordant pulmonary physiology: lessons from alpha1-antitrypsin deficiency. Chest 2007;132:909-15. http://dx.doi.org/10.1378/chest.07-0341

11. Omori $\mathrm{H}$, Nakashima $\mathrm{R}$, Otsuka N, et al. Emphysema detected by lung cancer screening with low-dose spiral CT: prevalence, and correlation with smoking habits and pulmonary function in Japanese male subjects. Respirology 2006; 11:205-10. http://dx.doi.org/10.1111/j.1440-1843.2006.00827.x

12. Wagena EJ, Kant I, van Amelsvoort LG, Wouters EF, van Schayck CP, Swaen GM. Risk of depression and anxiety in employees with chronic bronchitis: the modifying effect of cigarette smoking. Psychosom Med 2004;66:729-34. 
http://dx.doi.org/10.1097/01.psy.0000138127.00991.cf

13. Katz P, Julian L, Omachi TA, et al. The impact of disability on depression among individuals with COPD. Chest 2009;137:838-45.

14. Lindberg $A$, Larsson $L G$, Ronmark $E$, Jonsson AC, Larsson $K$, Lundback B. Decline in FEV1 in relation to incident chronic obstructive pulmonary disease in a cohort with respiratory symptoms. COPD 2007;4:5-13.

15. van der Molen T, Willemse BWM, Schokker S, Ten Hacken NHT, Postma DS, Juniper EF. Development, validity and responsiveness of the Clinical COPD Questionnaire. Health Qual Life Outcomes 2003;1:1-10. http://dx.doi.org/ 10.1186/1477-7525-1-13

16. Maleki-Yazdi MR, Lewczuk CK, Haddon JM, Choudry N, Ryan N. Early detection and impaired quality of life in COPD GOLD stage 0: a pilot study. COPD 2007; 4:313-20.

17. O'Reilly JF, Williams AE, Holt K, Rice L. Defining COPD exacerbations: impact on estimation of incidence and burden in primary care. Prim Care Resp J 2006; 15:346-53. http://dx.doi.org/10.1016/j.pcrj.2006.08.009

18. Makris D, Moschandreas J, Damianaki A, et al. Exacerbations and lung function decline in COPD: new insights in current and ex-smokers. Respir Med 2007; 101:1305-312. http://dx.doi.org/10.1016/j.rmed.2006.10.012

19. Donaldson GC, Seemungal TAR, Bhowmik A, Wedzicha JA. Relationship between exacerbation frequency and lung function decline in chronic obstructive pulmonary disease. Thorax 2002;57:847-52. http://dx.doi.org/10.1136/thorax.57.10.847

20. Andersson F, Borg S, Jansson SA, et al. The costs of exacerbations in chronic obstructive pulmonary disease (COPD). Respir Med 2002;96:700-08. http://dx.doi.org/10.1053/rmed.2002.1334

21. Niewoehner DE. The impact of severe exacerbations on quality of life and the clinical course of chronic obstructive pulmonary disease. Am J Med 2006; 119:38-45. http://dx.doi.org/10.1016/j.amjmed.2006.08.006

22. Langsetmo L, Platt RW, Ernst P, Bourbeau J. Underreporting exacerbation of chronic obstructive pulmonary disease in a longitudinal cohort. Am J Respir Crit Care Med 2008;177:396-401. http://dx.doi.org/10.1164/rccm.200708$12900 \mathrm{C}$

23. Fletcher C, Peto R. The natural history of chronic airflow obstruction. Br Med J 1977; 1:1645-8.

24. Scanlon PD, Connett JE, Waller LA, et al. Smoking cessation and lung function in mild-to-moderate chronic obstructive pulmonary disease. The Lung Health Study. Am J Respir Crit Care Med 2000;161:381-90.

25. Vestbo J, Sorensen T, Lange P, Brix A, Torre P, Viskum K. Long-term effect of inhaled budesonide in mild and moderate chronic obstructive pulmonary disease: a randomised controlled trial. Lancet 1999;353:1819-23. http://dx.doi.org/10.1016/S0140-6736(98)10019-3

26. Pauwels RA, Lofdahl CG, Laitinen LA, et al. Long-term treatment with inhaled budesonide in persons with mild chronic obstructive pulmonary disease who continue smoking. N Engl J Med 1999;340:1948-53. http://dx.doi.org/10.1056/NEJM199906243402503

27. Burge PS, Calverley PMA, Jones PW, Spencer S, Anderson JA, Maslen TK. Randomised, double blind, placebo controlled study of fluticasone propionate in patients with moderate to severe chronic obstructive pulmonary disease: the ISOLDE trial. BMJ 2000;320:1297-303.

28. Tashkin DP, Celli B, Senn S, et al. A 4-year trial of tiotropium in chronic obstructive pulmonary disease. N Engl J Med 2008;359:1543-54. http://dx.doi.org/10.1056/NEJMoa0805800

29. Decramer M, Celli B, Kesten S, Lystig T, Mehra S, Tashkin DP. Effect of tiotropium on outcomes in patients with moderate chronic obstructive pulmonary disease (UPLIFT): a prespecified subgroup analysis of a randomised controlled trial. Lancet 2009;374:1171-8. http://dx.doi.org/10.1016/501406736(09)61298-8

30. Celli BR, Thomas NE, Anderson JA, et al. Effect of pharmacotherapy on rate of decline of lung function in chronic obstructive pulmonary disease: results from the TORCH study. Am J Respir Crit Care Med 2008;178:332-8. http://dx.doi.org/10.1164/rccm.200712-18690C

31. Jenkins CR, Jones PW, Calverley PM, et al. Efficacy of salmeterol/fluticasone propionate by GOLD stage of chronic obstructive pulmonary disease: analysis from the randomised, placebo-controlled TORCH study. Respir Res 2009;10:59.

32. Bridevaux PO, Gerbase MW, Probst-Hensch NM, Schindler C, Gaspoz JM, Rochat T. Long-term decline in lung function, utilisation of care and quality of life in modified GOLD stage 1 COPD. Thorax 2008;63:768-74. http://dx.doi.org/10.1136/thx.2007.093724

33. Anthonisen NR, Connett JE, Murray RP. Smoking and lung function of Lung Health Study participants after 11 years. Am J Respir Crit Care Med 2002; 166:675-9. http://dx.doi.org/10.1164/rccm.2112096

34. Oga T, Nishimura K, Tsukino M, Sato S, Hajiro T, Mishima M. Exercise capacity deterioration in patients with COPD: longitudinal evaluation over 5 years. Chest 2005;128:62-9. http://dx.doi.org/10.1378/chest.128.1.62

35. Spencer S, Calverley PMA, Burge PS, Jones PW. Health status deterioration in patients with chronic obstructive pulmonary disease. Am J Respir Crit Care Med 2001; 163:122-8.

36. Price $D$, Crockett $A$, Arne $M$, et al. Spirometry in primary care caseidentification, diagnosis and management of COPD. Prim Care Resp J 2009; 18:216-23. http://dx.dol.org/10.4104/pcrj.2009.00055

37. Soriano JB, Zielinski J, Price D. Screening for and early detection of chronic obstructive Culmonary disease. Lancet 2009;374:721-32. http://dx.doi.org/10.1016/\$0140-6736(09)61290-3

38. Levy ML, Fletcher M, Price DB, Hausen T, Halbert RJ, Yawn BP. International Primary Care Respiratory Group (IPCRG) Guidelines: diagnosis of respiratory diseases in primary care. Prim Care Resp J 2006;15:20-34. http://dx.doi.org/10.1016/j.pcrj.2005.10.004

39. van den Boom G, van Schayck CP, Rutten-van Molken MPMH, et al. Active detection of chronic obstructive pulmonary diseas and asthma in the general population. Results and economic consequences of the DIMCA program. Am J Respir Crit Care Med 1998;158:1730-8.

40. Zielinski J, Bednarek M. Know the Age of Your Lung Study Group. Early detection of COPD in a high-risk population using spirometric screening. Chest 2001;119:731-6. http://dx.doi.org/10.1378/chest.119.3.731

41. van den Boom G, Rutten-van Molken MP, Folgering $H$, van Weel C, van Schayck CP. The economic effects of screening for obstructive airway disease: an economic analysis of the DIMCA program. Prev Med 2000;30:302-08. http://dx.doi.org/10.1006/pmed.2000.0633

42. National Institute for Clinical Excellence. Chronic obstructive pulmonary disease: management of chronic obstructive pulmonary disease in adults in primary and secondary care. 2010 update. Available from: http://guidance.nice.org.uk/CG101. Last accessed 16 July 2010.

43. Stratelis G, Jakobsson P, Molstad S, Zetterstrom O. Early detection of COPD in primary care: screening by invitation of smokers aged 40 to 55 years. $\mathrm{Br} J \mathrm{Gen}$ Pract 2004;54:201-06.

44. Derom E, van Weel C, Liistro G, et al. Primary care spirometry. Eur Respir J 2008;31:197-203. http://dx.doi.org/10.1183/09031936.00066607

45. Lusuardi M, De Benedetto F, Paggiaro P, et al. A randomized controlled trial on office spirometry in asthma and COPD in standard general practice: data from spirometry in Asthma and COPD: a comparative evaluation Italian study. Chest 2006;129:844-52. http://dx.doi.org/10.1378/chest.129.4.844

46. Calverley PM, Nordyke RJ, Halbert RJ, Isonaka S, Nonikov D. Development of a population-based screening questionnaire for COPD. COPD 2005;2:225-32.

47. van Schayck CP, Loozen JMC, Wagena E, Akkermans RP, Wesseling GJ. Detecting patients at a high risk of developing chronic obstructive pulmonary disease in general practice: cross sectional case finding study. $\mathrm{Br}$ Med J 2002; 324:1370-4.

48. van Schayck C, Levy M, Chen J, Isonaka S, Halbert R. Coodinated diagnostic approach for adult obstructive lung disease in primary care. Prim Care Resp J 
2004;13:218-21. http://dx.doi.org/10.1016/j.pcrj.2004.07.001

49. Price DB, Tinkelman DG, Nordyke RJ, Isonaka S, Halbert RJ, for the COPD Questionnaire Study Group. Scoring system and clinical application of COPD diagnostic questionnaires. Chest 2006;129:1531-9. http://dx.doi.org/ 10.1378/chest.129.6.1531

50. Freeman D, Nordyke RJ, Isonaka S, et al. Questions for COPD diagnostic screening in a primary care setting. Respir Med 2005;99:1311-18. http://dx.doi.org/10.1016/j.rmed.2005.02.037

51. van Schayck CP, Halbert RJ, Nordyke RJ, Isonaka S, Maroni J, Nonikov D. Comparison of existing symptom-based questionnaires for identifying COPD in the general practice setting. Respirology 2005;10:323-33. http://dx.doi.org/10.1111/j.1440-1843.2005.00720.x

52. Price DB, Tinkelman DG, Halbert RJ, et al. Symptom-based questionnaire for identifying COPD in smokers. Respiration 2006;73:285-95. http://dx.doi.org/10.1159/000090142

53. O'Donnell DE, Hernandez P, Kaplan A, et al. Canadian Thoracic Society recommendations for management of chronic obstructive pulmonary disease 2008 update. Can Respir J 2008;15 Suppl A:1A-8A.

54. Celli BR, MacNee W, and committee members. Standards for the diagnosis and treatment of patients with COPD: a summary of the ATS/ERS position paper. Eur Respir J 2004;23:932-46. http://dx.doi.org/10.1183/09031936.04.00014304

55. Johannessen A, Omenaas ER, Bakke PS, Gulsvik A. Implications of reversibility testing on prevalence and risk factors for chronic obstructive pulmonary disease: a community study. Thorax 2005;60:842-7. http://dx.doi.org/ 10.1136/thx.2005.043943

56. Tinkelman DG, Price DB, Nordyke RJ, et al. Symptom-based questionnaire for differentiating COPD and asthma. Respiration 2006;73:296-305. http://dx.doi.org/10.1159/000090141

57. Hyland ME, Jones RC, Hanney KE. The Lung Information Needs Questionnaire: Development, preliminary validation and findings. Respir Med 2006;100:180716. http://dx.doi.org/10.1016/j.rmed.2006.01.018

58. Anthonisen NR. Smoking, lung function, and mortality. Thorax 2000;55:72934. http://dx.doi.org/10.1136/thorax.55.9.729

59. Pelkonen $M$, Tukiainen $H$, Tervahauta $M$, et al. Pulmonary function, smoking cessation and 30 year mortality in middle aged Finnish men. Thorax 2000;55: 746-50. http://dx.doi.org/10.1136/thorax.55.9.746

60. Casaburi R, Kukafka D, Cooper CB, Witek TJJr, Kesten S. Improvement in exercise tolerance with the combination of tiotropium and pulmonary rehabilitation in patients with COPD Chest 2005;127:809-17. http://dx.doi.org/10.1378/chest.127.3.809

61. Price D, Freeman D, Kaplan A, Ostrem A, Reid J, Molen T. Progressive breathlessness in COPD - the role of hyperinflation and its pharmacological management. Prim Care Resp J 2005;14:285-93. http://dx.doi.org/ 10.1016/j.pcrj.2005.08.005

62. Freeman D, Lee A, Price D. Efficacy and safety of tiotropium in COPD patients in primary care - the SPiRiva Usual CarE (SPRUCE) study. Respir Res 2007;8:45 http://dx.doi.org/10.1186/1465-9921-8-45

63. Celli BR. Chronic obstructive pulmonary disease: from unjustified nihilism to evidence-based optimism. Proc Am Thorac Soc 2006;3:58-65. http://dx.doi.org/10.1513/pats.200510-111JH

64. Beeh KM, Beier J, Buhl R, Stark-Lorenzen P, Gerken F, Metzdorf N. [Efficacy of tiotropium bromide (Spiriva) in patients with chronic-obstructive pulmonary disease (COPD) of different severities]. Pneumologie 2006;60:341-6. http://dx.doi.org/10.1055/s-2005-919145

65. Johansson G, Lindberg A, Romberg K, Nordstrom L, Gerken F, Roquet A. Bronchodilator efficacy of tiotropium in patients with mild to moderate COPD. Prim Care Resp J 2008;17:169-75. http://dx.doi.org/10.3132/pcrj.2008.00037

66. Dusser D, Bravo ML, lacono P. The effect of tiotropium on exacerbations and airflow in patients with COPD. Eur Respir J 2006;27:547-55. http://dx.doi.org/10.1183/09031936.06.00062705

67. Morice AH, Celli B, Kesten S, Lystig T, Tashkin D, Decramer M. COPD in young patients: A pre-specified analysis of the four-year trial of tiotropium (UPLIFT). Respir Med 2010 [Epub ahead of print].

68. Troosters $T$, Kesten $S$, Burkhart $D$, et al. Effectiveness of tiotropium as first maintenance drug in patients with COPD. Secondary analysis of the UPLIFT trial. Am J Respir Crit Care Med 2009;179, A2467.

69. Crockett AJ, Price D. Co-morbid disease in COPD - more than a coincidence. Int J Chron Obstruct Pulmon Dis 2007;2:399-400.

70. Decramer M, Rennard S, Troosters T, et al. COPD as a lung disease with systemic consequences--clinical impact, mechanisms, and potential for early intervention. COPD 2008;5:235-56.

71. Fabbri LM, Luppi F, Beghe B, Rabe KF. Complex chronic comorbidities of COPD. Eur Respir J 2008;31:204-12. http://dx.doi.org/10.1183/09031936.00114307

72. Watz H, Waschki B, Boehme C, Claussen M, Meyer T, Magnussen H. Extrapulmonary effects of chronic obstructive pulmonary disease on physical activity: a cross-sectional study. Am J Respir Crit Care Med 2008;177:743-51. http://dx.doi.org/10.1164/rccm.200707-10110C

73. Grabicki M, Parysek H, Batura-Gabryel H, Brodnicka I. Comorbidities as an element of multidimensional prognostic assessment of patients with chronic obstructive pulmonary disease. J Physiol Pharmacol 2008;59 Suppl 6:297-301.

74. Eickhoff P, Kiss D, Kohansal R, Valipour A, Geyer K, Burghuber C. Endothelial dysfunction in stable COPD - a link between systemic inflammation and cardiovascular morbidity? Eur Respir J 2006;28 Suppl 50:116s.

\section{Available online at http://www.thepcrj.org}

